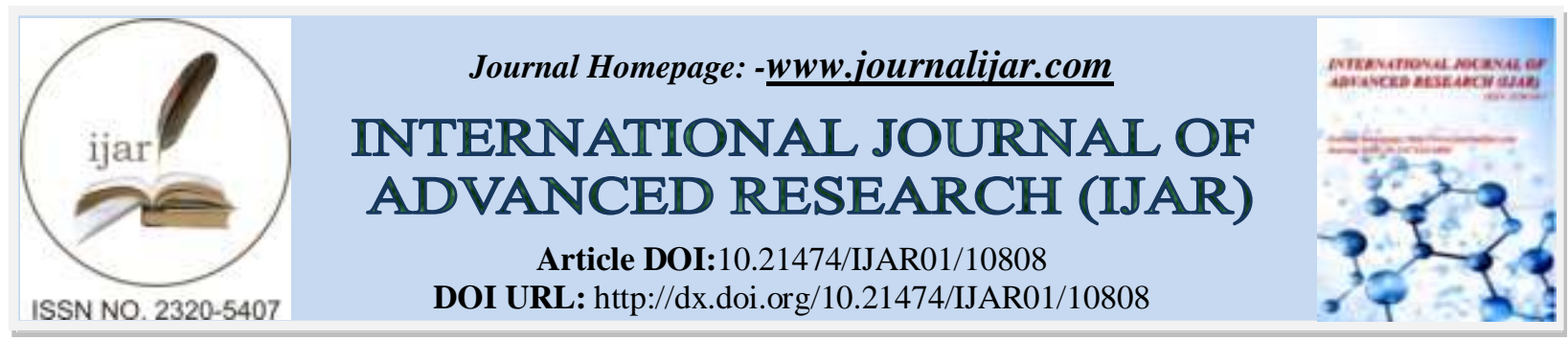

RESEARCH ARTICLE

\title{
INEQUALITY AND VIOLENCE IN URBAN SPACE: A CASE OF NEOLIBERAL DHAKA
}

Saiful Islam ${ }^{1}$ and Josinta Zinia ${ }^{2}$

1. Lecturer, Department of Sociology, Bangladesh University of Professionals.

2. Associate Professor, Department of Sociology, Bangladesh University of Professionals.

\section{Manuscript Info}

Manuscript History

Received: 12 February 2020

Final Accepted: 14 March 2020

Published: April 2020

Keywords:-

Violence, Urban Space, Urban Poor,

Neoliberalism

\begin{abstract}
In a world in which more than half of the population lives in cities, rising urban violence has emerged as a huge concern of policymakers, especially as it is a major challenge to development in the Global South. The most marginalized - the urban poor-suffer more as violence is concentrated in their living spaces. This study aims to explain the political economy of urban violence in Bangladesh. As the capital of Bangladesh, Dhaka city has become a highly unequal society where neoliberal economic restructuring is continuously depriving the urban poor of all sorts of urban services. It addresses privatization of the urban space and exclusion of the urban poor which make them often violent. It further explores the governance of urban violence by the neoliberal state. The paper is based on data collected from the city of Dhaka where millions of urban poor are struggling for shelters. It reveals that the urban poor is the victims of neoliberal urban development as they are being displaced from where they used to live as squatters for a long period. Due to their poverty and marginality, they are unable to get shelter nearby the places they were living. Many of them move to suburban Dhaka where they often struggle to get jobs. Neoliberal urban development often causes violence and protests in the city of Dhaka. It also reveals that the neoliberal state uses security forces to evict the urban poor and compel them to move to the urban peripheries. However, the paper argues that increasing urban violence in the city of Dhaka is linked to the privatization of urban space and the exclusion of the urban poor from neoliberal urban development. It further argues that the neoliberal state serves the interests of affluent and business people ignoring the right of the millions of urban poor to the city.
\end{abstract}

Copy Right, IJAR, 2020,. All rights reserved.

\section{Introduction:-}

The world is becoming increasingly urbanized and for the first time in history, half of the world's population lives in cities. In 2018, an estimated 55.3 per cent of the world's population lived in urban settlements. By 2030, urban areas are projected to house 60 per cent of people globally and one in every three people will live in cities with at least half a million inhabitants (United Nations, Department of Economic and Social Affairs, Population Division, 2018). With over 42 million urban residents, Bangladesh has one of the largest urban populations in the world 2 
(Mansour, Islam \&Akhtaruzzaman, 2017). Dhaka is the largest and fastest-growing urban center in Bangladesh with a population density of 44,500/km2 (UN Habitat, 2017). One-tenth of the country's population and a third of its urban population (36\%) live in Dhaka (Bird et al., 2018). It is the 9th largest city in the world and projected to become the 4th largest by 2030 (United Nations, Department of Economic and Social Affairs, Population Division, 2018).

As the capital of Bangladesh, Dhaka city has become a highly unequal society where neoliberal economic restructuring is continuously depriving the urban poor of all sorts of urban services. The urban poor is mostly employed in low-paid jobs in the informal sector with limited access to formal sector employment. They have limited access to land and mostly settle in sub-standard/poor quality housing built on vacant public and private land; often forced to move to low-lying peripheries of the city. Utility services such as water supply, sanitation and garbage disposal services are poor in quality or non-existent. They also suffer from poor nutrition, insufficient access to health care services and limited access to education. (Hossain 2004b; 2006a). Moreover, the rapid urbanization and privatization of services have accelerated serious discontents and misery for the urban poor who used to live in various informal settlements or urban slums of the cities (Haque 2012). So, the concept 'Right to the City' for the poor has become a far cry which is regulated by the market-driven neoliberal policies.

In recent times urban crime and violence have featured as a prominent issue in Dhaka. It is estimated that 17 percent of the total crimes of the country are committed in Dhaka city and out of 80 known organized criminal syndicates in Bangladesh, 28 of them function in Dhaka city (Shafi 2010). In an urban household survey, the lack of security was rated as the second major problem after problems with utility services like water and roads (Shafi 2010). Why have crime and violence and the rise of personal insecurity grown to such significance in Dhaka? Many middle classes and upper-class inhabitants would identify poverty and inequality as the main reason, attributing the rise of urban crime to deprivation and the illegal informal economy in urban slums (Hossain 2011). However, crime and violence have socio-economic and political roots and are perpetuated how public goods and services are managed and delivered in the city. Increasing urban violence in the city of Dhaka is linked to the privatization of urban space and exclusion of the urban poor from neoliberal urban development. The neoliberal state serves the interests of affluent and business people ignoring the right of the millions of urban poor to the city. In this context, the paper addresses privatization of the urban space and exclusion of the urban poor which make them often violent. It further argues that rising inequality and resulting incidents of crime and violence, call for higher attention to inclusion in urban areas. Social inequality fosters violence, which in turn creates more inequality. Thus, any effort to reduce violence must be accompanied by efforts to reduce inequality. 3

\section{Theoretical and Conceptual Framework for the Study:}

\section{The Political Economy of the Production of Urban Space in Dhaka City:}

Social scientists have considered urban space a social product, the outcome of numerous human interactions. People constitute urban space and, conversely, to a certain degree urban space structures the behavior of urban residents. In Henry Lefebvre's (1974) view, urban space is produced through contentious processes whether instrumented by or in a combination of local, national, transnational and global actors. Lefebvre argued that "space is becoming a central object of political struggle in the contemporary world - it is no longer the 'medium' or 'theatre' of sociospatial conflicts but one of their constitutive dimensions." The production of urban space is, therefore, a political economy process that is necessarily linked with capitalist accumulation through spatiotemporal articulation leading to both winners and losers. Lefebvre (2009) in his book 'The Production of Space' purports that space reproduces spatial code that restricts activity in space, commands bodies, prescribes and proscribes gestures, routes and distances to be covered. Lefebvre captures our attention to the critical phase of the city - 'the harbinger of the certain globalization of the urban'. This critical phase has been brought into light by exemplifying it with the pros and cons of streets. Lefebvre argues that the highly-trafficked and busy street provides security against criminal violence such as theft, rape or assault. So vanishing of street intensifies criminality. Against the street, he postulated that streets have become a form of oppression or subjugation. Movement in the street has become not only mandatory but also repressed.

Castells (1977) initially considers the city as the projection of society on space in his conceptualization of urban space. Then he continues, "space is a material product, in relation to other material elements - among others, men, who themselves enter into particular social relations, which give to space a form, a function, a social signification." In a natural progression from such conceptualization of space as a component of broader social theory, Castells (1977) defines an urban system as "specific articulation of the instances of a social structure within a (spatial) unit of 
the reproduction of labour power." He sums up 'urban' and 'urban space' respectively as a connotation of labourpower reproduction process and a manifestation of its unit of articulation. This study adopts Castells' approach by highlighting urban space as an outcome of material social relations. It specially focuses upon how variation in power relations between different stakeholders of urban space determines the latter's use leading to differential returns for the former.

The production of urban space is no more viewed as mere social functions but also as material outcomes of complex political-economic processes that are multiple and overlapping. David Harvey $(1973,1985)$ is widely identified with the paradigm shift to political economy in thinking of urban spatiality across social science disciplines. His works about urban space are much occupied by critical political economy concerns like capital accumulation, regimes of 4accumulation, inequality, and uneven geographical development, spatial division of labour and crisis-induced restructuring. Harvey (2009) argued that the city and the quality of urban life have been commodified. Urban living is now accompanied by shopping malls, multiplexes, cafes, departmental stores, fashion industry, cultural and knowledge-based industries. He observed threatening of urban identity, citizenship and belonging as well as individual security in the face of criminal activity promoted by a neoliberal ethic. But he particularly focused on the fortification of the city and creative dispossession.

Harvey (2003a) introduced the concept of 'accumulation by dispossession' that reconceptualized Karl Marx's concept of primitive accumulation. Karl Marx in his classic Capital (volume 1) describes primitive accumulation as a set of processes that take place at the formative stage of capitalism. The long list includes, as summarized by Harvey (2003), commodification and privatization of land and resulting forceful expulsion of peasant populations, conversion of common and collective property rights exclusively into private property rights, the commodification of labour power, suppression of indigenous forms of production and consumption, colonial and imperial appropriation of assets and natural resources, monetization of exchange, taxation and land, slave trade, national debt and credit system. In other words, accumulation may begin with the emergence of capitalism but doesn't end there. Rather predation, fraud and violence that are characteristic of primitive or original accumulation persist as means of capitalist development. To capture this reality of capitalism, Harvey (2003a) contextualized primitive accumulation in the current practice of capitalism as accumulation by dispossession. Harvey (2003b) then showed accumulation by dispossession in the urbanization process that is obstructing common peoples' right to the city. Under capitalist urbanization through accumulation by dispossession, the city embodies individual command of resources at the expense of collective rights of common city dwellers. This study analyzed accumulation by dispossession as a constituent of capitalist urbanization process: accumulation with capitalist political-economic elite and dispossession mainly with the working class and socio-spatially marginalized peoples.

\section{Explaining Urban Violence:}

Violence is a confounding concept. Over the past two decades, urban violence has acquired increasing visibility and impact for sociology as a discipline, yet has often been dispersed and fragmented into specialist areas of analysis. Sociologists have contributed much to the intellectual understanding of violence as social processes and institutions; there are a multiplicity of sociological theories and perspectives.

In the Global South, there is a tendency to articulate urban violence as an aspect of (under)development or conflict (Moser \&Mcllwaine, 2006). Urban violence is above all socially and economically motivated. Urban residents, especially in poor or peripheral areas, face the daily impact of violence and insecurity as a result of a specific form of state failure. Urban violence is not random. Just as many different types of urban violence can be 5categ orized as political, social, economic and institutional, so the causes of such violence are multiple and need to be understood from a holistic perspective. The causes of urban violence must be viewed from a multi-disciplinary and multi-scalar perspective. It is widely recognized that no single factor underpins its emergence. Instead, these range from psychosocial theories linked with socialization processes to much wider macro-economic trends that relate to poverty and inequality. It is important to view the causes from a combination of structural, institutional, interpersonal, and individual levels, all of which are interrelated. This perspective is incorporated within the 'ecological model' or epidemiological' approach which has since been popularized by violence researchers as well as by international agencies like UN Habitat (2007) and the WHO (2002). The adapted version identifies various contributory factors relating to psychological, social and familial, economic, cultural, political and institutional issues.

At the structural level, the most commonly identified underlying causes of urban violence include deep-seated inequalities in the distribution of economic, political and social resources which themselves are interrelated with 
poverty and are underpinned by globalization and neo-liberal macro-economic and political processes. Related to these at the institutional level are unemployment and exclusion from labour markets, as well as ineffective judicial and state security systems combined with impunity. These factors facilitate the emergence and proliferation of a wide range of different violence actors, especially when linked with spatial exclusion within cities where the poor reside in marginal settlements where the state plays a limited role and where alternative violent actors thrive. The present study focuses on the social exclusion, poverty and inequalities in the distribution of economic, political and social resources those related to the structural causes of urban violence.

This study argues that urban violence is integral to everyday urban experiences. The city, in all its social and structural forms, contributes to, creates space for, and amplifies or dampens violence, in ways that do not happen in rural or non-urban areas. The inevitable dynamics of new urbanization, such as large-scale in-migration and informal settlements, create conflict and violence in sometimes unexpected or unpredictable ways, which require sociologists to expand their ideas of urban violence. This urban violence is inherent to urban power relations and their spatial expressions (Brenner, Jones, MacLeod, \& Jessop, 2003). Violence has an enormous potential impact on the production of urban space. Violence re-orders space and violent space-making is a social process. Different social forces struggle to impose their spatial strategies, and while some do this violently, producers of space at the other end of the spectrum develop spatial strategies to cope with violence. Social interactions, physical encounters of space-making agents, and violent impacts on the material environment shape city space. This urban space is constituted both by daily violence and by stretching along with neoliberal operation of the capitalist economy. Moreover, this urban violence affects the most disadvantaged populations in disproportionate ways.

\section{Neoliberal Urban Transformation of Dhaka City:}

Bangladesh is currently facing the new challenges of rapid urbanization. The city of Dhaka has emerged as one of the most rapid-growing cities in the world. The urbanization of Dhaka is closely connected to the crisis in agriculture and rural displacement due to implemented structural adjustment policies in recent decades and massive migration of rural population to the city with the hope of prosperity. The fact is, most of the new poor migrants are taking places in the peripheries of the city which become the major pockets of poverty. Adjunct areas to the city including Kamrangir Char, Savar, Toungi, Gazipur, Demra, Chachpur and Narayanganoj are attracted by the new poor migrants due to low cost for housing. In addition, poor people from the city center are also forced to be moved to these new suburbs due to the increasing demand of land for the new commercial establishments and housing for upper and middle-income groups. A huge number of real estate companies have emerged in the last decade which are mostly involved for building houses for affluent classes. In the name of beautification of the city,several projects were taken by the authorities with the help of private developers also displace a huge number of poor people from the city centre who are also taking shelter in the new urban peripheries. Thus way, the new urban peripheries become the new pockets of marginalized communities in recent times.

The poor migrants are mostly excluded from the formal sectors of the economy and they are involved in the peripheral economic activities. Informality becomes the new way of urban life and the migrants are mostly involved in different informal sectors of the economy. A significant portion of the poor migrants is involved in garments factories which are mostly shifted to the new urban peripheries of the city. Savar is one of the new suburbs where more than a thousand garments workers have recently died due to collapse of a building. This area has been developed as an export export-processing zone in the last decade where workers across from the country joined. Every year a huge number of destitute populations from rural areas are joining to this area. Similarly, Gazipur and Narajangong have also become the new home of poor migrants from the different rural districts of the country. However, the neoliberal urban transformation of Dhaka has made it as the destiny of the new urban poor.

\section{Rising Urban Inequality and Poverty:}

Neoliberal urbanization of Dhaka is directly linked to inequality and poverty. Millions of urban poor are living in urban peripheries who are mostly involved in different peripheral economic activities. Whereas small percentages of the urban population are being extremely benefited through the process of urban renewal and redevelopment.Having mentioned that, a huge number of established has been taken place in the city in recent decades for the expansion due to the new economic restructuring. The number of financial institutions and regional offices of corporations has been made the city as corporations. With the process of privatization under neoliberal transformation, a huge number of private schools, universities and hospitals have been established where the neo-rich only have the accesses. Both government and private sectors havedeveloped housing projects for the powerful and affluent classes. There is no mentionable project for the low-income group in the city. Although there was a housing project was 
undertaken for the urban poor previously living in the area, they did not get accesses to the flats. Most of them were occupied the people who connections with ruling parties over the decade. In fact, the city of Dhaka has become the display of advertisements of the real estate companies which often give lucrative offers of land and housing. Television channels telecast news and programs often being sponsored by private housing developers, private hospitals and other private companies.

In the name of beautification of the city, the government authorities have recently inaugurated 'Haterjeel' projects which have become the new place of sight-seeing for rich and middle-income groups. It needs to be mentioned here that almost a half a million poor people who used to live in the site are displaced by the project and many of them have moved to the new suburban areas. Other projects similarly displace the marginal communities from the city. The cultural spaces of the city have been significantly transformed with economic changes. The city has emerged as the city of restaurants and beauty parlor and jemnisum. Wealthy suburbs like Gulshan and Banani have developed as the places of amusements of the neo-rich who have mainly accumulated capital through accumulation by dispossession (Harvey, 2009). The privatization of urban space creates a displacement of the poor from the city. Culturally the city has emerged as the 'fragmented city'.

Residential segregation has created the 'city of walls'. The poor living in a poor neighborhood has emerged as the new enclaves of poverty. The poor are often treated as the criminal by the state. Punishing the poor becomes the main agenda of neoliberal Bangladeshi state. Once any crime happened in the city police raid in the urban slums where the poor people are living. For example, the new suburb Kamrangirchar is often treated is a criminal zone. Police often search for different criminals in this neighborhood. People living in upper and middle-class suburbs like Dhanmondi and Mohammadpur consider the area as the other parts of the city where criminals and dangerous persons are residing. Even people from wealthy suburbs are scared of visiting the area. Whereas a huge number of informal workers are living in there who are significantly contributing to the urban economy. Similarly, wealthy sections living in Gulshan and Banani are very much dependent on the services of poor communities living in Korail, the largest slum in Dhaka which is located other sides of the lake. However, the fortified enclaves are developing in Dhaka through urban planning and policy over the decades.

Life and labor of the people in neoliberal Dhaka need to be explored to understand the conditions of the new working class. The new urban poor are mostly involved in the peripheral activities in the urban economy. Most of them are involved in rickshaw pulling, pretty trading and street selling, transport sector, construction sites, garments factories and personal services. Some of them are working as security guards and low-grade employees of the government and private establishments. Women workers have mostly involved in garments factories and maid servants in the residence of affluent classes. Although they are earning more than their counterparts in their villages, they are income is insufficient for managing their daily lives in the city in the contexts of increasing prices of food and non-food items. Moreover, they became unemployed and underemployed. The current political chaos in the country seriously affects the lives of the urban poor. Most of them are unable to go to work during strikes and unable to manage their families which causes huge stress and anxiety among them. They are often harassed at their workplace by their employers and the police depending on the nature of the jobs. Risk and insecurity in the workplace are huge. But they are not in a position to say 'no' to the risk involved job because of vulnerabilities. Thousand of garments workers were forced to enter a damaged building by the employers which was ultimately collapsed and more than thousand died and many of them seriously injured who will not be able to return to their work in their lifetimes. This reveals the vulnerabilities of the workers working in the garments industry which has been emerged as the main source of employment for the new urban poor.

The new urban poor are living in slums and slum-like conditions. Shelter becomes an important issue for redefining urban poverty in Dhaka. Although many of them improved their conditions in terms of their income and food consumptions they are marginalized in terms of their housing. Housing for poor urban communities becomes the most important agenda for the urban planners and policy-makers. They have very limited access to urban infrastructure services like supply drinking water, sanitation, electricity and gas. Moreover, the poor settlements developed in the urban peripheries where industries and factories are located. A huge number of poor people are suffering from the tannery industry in Dhaka. In fact, the poor urban communities the real victims of environmental injustices (Flammable). Despite living in the city for a long period of them they have limited access to urban systems. Sometimes they develop a different form of urban adaptations which are often labelled as anti-urban by the powerful and affluent classes. It is true that due to life-long experiences of poverty they might develop a different fife-style as a defensive mechanism. It is also true that living in a poor neighborhood often stigmatizes them. They 
live in the city as an urban outcast (Wacquant 2001) In fact, living with poverty for a long period of time is not the cause, rather it is an effect. The real cause of poverty is their victimization by the state and market. The invisible hands of state and market punish the poor communities in neoliberal Dhaka.

The New Urban Violence and its links with the Neoliberal Transformation of Dhaka:

Dhaka has emerged as the city of chaos where unprecedented public violence is occurring in recent times. It is estimated that 17 percent of the total crimes of the country are committed in Dhaka city and out of 80 known organised criminal syndicates in Bangladesh, 28 of them function in Dhaka city (Shafi 2010a). In an urban household survey, the lack of security was rated as the second major problem after problems with utility services like water and roads (Shafi 2010a). Why have crime and violence and the rise of personal insecurity grown to such significance in Dhaka? Many middle class and upper class inhabitants would identify poverty and inequality as 9the main reason, attributing the rise of urban crime to deprivation and the illegal informal economy in urban slums (Hossain 2011). However, crime and violence have political roots and are perpetuated by the way in which public goods and services are managed and delivered in the city. Different forms of public violence have been produced mainly through the denial of citizenship rights including access to land and housing and urban utilities; frequent protests by informal workers and garments workers. In most of the cases, these forms of protests ended with violence and damages of public and private properties. All forms of violence are closely linked to the new economic restructuring and increasing social insecurity and uncertainties.

Denial of citizenship rights has made the city of Dhaka as an insurgent city (Holston 2009). A huge number of insurgent citizens are living in the urban peripheries of the city without having access to the amenities of urban life. The right to housing becomes crucial for increasing chaos in the city of Dhaka. Over the years a huge number of urban populations lived as squatters who are being recently evicted from their settlements without their rehabilitation. Urban renewal produces huge tension and violence in the city. Almost a half a million poor people are living in Korail, the largest slum in Dhaka which was developed in public land more than twenty years ago. Now the land becomes very lucrative as it is near the wealthiest suburbs of Dhaka (Gulshan and Banani). Parties including government, private developers, local leaders are involved to get control over the land. Huge tension continues in the areas as there was an order from the High Court infavor of the poor people living there. Recently more than a hundred thousand residents protested against eviction by the authorities and finally, it was stopped. In EarshardNagor near Tongi, the poor communities were resettled in the early-eighties while it was too far for the city centre. Currently, huge tension is observed in the area due to the fear of evictions by the authorities in the context of an increasing demand for land. The fact is, evictions of poor people from the city centre often causes huge violence in the city. The poor people become violent to keep control their right to the land.

Control over urban land in Dhaka becomes the source of crime and violence in the city. Government, private developers and professional groups are trying to capture land in urban peripheries in Dhaka City. A huge number of new housing projects are developing for different professional groups and emigrants mostly settled in the Western world. Housing projects are developing in the name of Westerns countries/cities. The Land is often taken from the owners who were living there over the decades through cheating and giving them less or no money. The fact is, the land price has been increased unusually and sometimes the rates of increase are more than that of other global cities in the Western world. Increasing land value creates huge tension and violence in the city. One of the protests made in Rupjang under Narayangong, near the City of Dhaka where local residents protested against the authority to protect their land as they did not want the project of government on their land. Protesters were killed and the government had to stop the project. Similarly,the government had to stop another project of an airport in Mankiganj while local residents became violent to the authorities. These are recent protest by the locals for protecting 10their land. But the question is whether they will be able to hold their control over their land in the near future as land is needed for neoliberal urban expansions.

Land grabbing is the cause of recent urban crimes and violence. Real estate companies are often blamed as responsible for land grabbing. Frauds, kidnapping and killing are common forms of crime which are related to urban land in the greater Dhaka. In many cases, urban land is occupied by the parties through connections with political parties. In many cases, the owner of the land is tortured and forced to leave the place. Local mastans and terrorists are used to force them. Every year a huge number of land-related cases are filed in different police stations in greater Dhaka- Savar, GazipurKeraniganj and Narayanjong. As the cases are unusually lengthy and influenced by the powerful parties who are involved in land grabbing process, the victims do not get justice. Many intermediaries are involved in the processing of buying and selling land in the peripheries of Dhaka. In fact, it is a huge challenge to 
continue the possession of land in urban peripheries by the landowners as the land grabbers are very powerful in society.

Urban services are the crucial basis for the new urban conflicts as Manuel Castells argued a couple of decades back. His predictions are also appropriate for the megacities like Dhaka. Along with housing, access to basic urban services like water, electricity and gas become crucial for Dhaka. Often urban protests are observed in the city for urban services. It would be useful to mention an example of urban protest in Jatrabari, Dhaka for regular access to electricity during the tenure of the last government (BNP). Local residents continued the strike to full-fill their demand. Local members of Parliament (MP) tried to meet the protesters who became very violent to him. He finally escaped from the place with the help of law-enforcing agencies. Huge tensions are observed in the city for frequent loadshading in the city. Wealthy suburbs are experiencing irregularities of electricity than the suburban areas where the poor people are living. In many slums and squatters have no legal access to electricity and they are paying more for using very limited use of it (a single bulb is used). A number of power brokers are involved who are working for intermediate groups.

Water is another source of urban conflict and violence in the city of Dhaka. The supply of water in the city is inadequate and the quality of water is poor. Although many parts of the city are experiencing the problem of supply water but the poor urban communities severely affected. It is observed that the poor are struggling to get safe drinking water. Long waits for collecting water in the poor neighborhood is a very common phenomenon. In a number of places residents especially poor residents made protests for safe drinking water. In the squatter settlements, poor are extremely experiencing the problem of safe drinking water. Due to their vulnerability, they are often dependent on the middlemen who are making business with the water. They got connections from the authority and they are providing water to the poor residents at a higher cost. In Korial, it has been found that few people are making huge money through this business. It 11 reveals from the daily newspapers that protests in Dhaka City over the period due to lack of access to water. The quality of water is very poor and discontents on the quality of water are very common among the residents in the city especially in the poor neighborhoods.

Another source of conflict is the inadequate access to gas which are mainly used as fuel in the city. Despite living in the city many of the residents especially poor residents have no access to gas although the government is planning to export gas to the neighboring country. In the last couple of years, the government did not give permission for new gas lines to the new housing projects which creates huge tensions and conflicts among the new house/flat owners. As power and connection, the government has taken the decision to give new connections. Moreover, the government wants to satisfy the neo-rich and professional groups who are very important to them. Whereas significant areas of the greater Dhaka is out of service. Especially the new suburbs where the poor people are residing have no adequate to access to the gas supply.

Employment and livelihood are an important source of tension and conflict. As the poor are urban communities are mostly involved in low paid employments like rickshaw pulling, driving, street vending and garments factories. Regulation of urban space in the city of Dhaka is creating huge chaos in the city. Road blocking is creating problems for the rickshaw pullers as they are unable to move with passengers. Most of rickshaw pullers express their anger over the police who block their roads and the police often harass them in different ways. Police often takes rickshaw from their pullers who have no registration numbers or something like that. Most of the city dwellers are dependent on public transports and rickshaws. Passengers are also fed up with the behavior of police as they need to use rickshaw for their short travel in the city. Only five percent residents are using private cars in the city. Most of the policies and planning have been taken by the government support the neo-rich who are using private cars. Drivers of CNG often go for strikes for their demands which also cause tension in the city.

A huge number of people are involved in the informal economy especially street vending in the city of Dhaka. People involved in informal sectors use a different mechanism to survive in the city. Informal survivalism becomes a new mode of urban adaptation. They are significantly contributing to the urban economy despite it is often ignored. Gradually the sector has been expanded where a huge number of urban poor find their jobs. Due to the contested urban space government often evict them from their business. In fact, the regulation of urban space becomes one of the key challenges for the urban government. The authorities often evict the street vendors form the street which also produces huge chaos in the city. Often they are being displaced from their business as the urban space needed for the new urban development. It reveals that the fight between the street vendors and the law enforcing agencies especially police is a very common phenomenon in Dhaka. During the period of interim 
government, the authorities took initiatives to evict the street vendors from the street which cause huge tension in the city. Through huge protest and violence street vendors again settled their business in the street.

Garments produce huge tension and anxiety in the city of Dhaka. These garments factories emerged as the main industry in the last couple of decades. Now the greater Dhaka has become the production centre for the readymade garments for the western world. Garments factories are largely concentrated in the new suburbs including Savar, Asulia, Toungi, Gazipur and Narayangonj. Still, there are a number of garments factories in the city centre which are also being relocated to the new urban peripheries. Having mentioned that, these new suburbs are targeted by poor migrants due to low-cost housing. Garments workers are getting low wages and they often protest in for raising their pays. They often block roads and organize protests in the Savar, Asulia, Khancpur and Narayangog. Sometimes they become violent to the authorities as they always want to end the protests. The state always in the favor of owners of the garments and ignore the demands of the workers. The fact is, they are working long hours but they are not getting their dues. The condition of working place is not unsafe. They are the victims of different accidents in the city. In the last year, more than one hundred garments workers were burnt in Tazin Garments located in Savar which attract huge attention. This year one of the severe accident has taken place which is known as 'Savar Tragedy'. More than a thousand garments workers working in Rana Plaza died due to its collapse. Other thousands of workers are injured many of them will not be able to return to the workforce as they have lost their legs or hands. The political economy of the recent accidents needs to be studied.

Neoliberalism is an attack on women's liberation. It has made women into workers, including low-wage workers, who work long hours, who are made to feel "responsible" for those long hours spent away from their homes children and family, because patriarchy lives on, but in new forms. Women now have the double burden, as some call it, of providing resources and income as well as care for the family in a system that doesn't have adequate health care provision for its citizens, a system that doesn't make child care a priority which means most workplaces don't have child care options, where elder care is supposed to be provided by family members, whether or not they are able to. Sexual harassment at the work place, and on the streets, rape on public transportation, harassment on the way and back from work - all of these persist because neoliberalism while prioritizing competition and efficiency has made women part of the work force, has not made the environment friendly towards them. It hasn't dismantled the system that has historically oppressed women and continues to oppress women. Instead, it has created isolation. So when women experience all these forms of oppression - at the home, workplace, and on the streets - they have nowhere to turn for real help, which means the violence against them is maintained over time, in more and more locations.

The nature of violence in Dhaka city indicates the volatile effects of extreme inequality of access as well as the way in which public goods are delivered and managed. In the absence of an effective and equitable formal delivery mechanism, a network of powerful local leaders complicit with public officials and politicians are able to provide services in exchange for rents. Some of these public goods are used as instruments of political patronage, ensuring loyaltyand support for a particular political faction. In some cases, small businesses and trades in the informal economy pay exorbitant rents to buy protection. Violence and insecurity are perpetuated through a top-down process driven by the powerful through a chain of networks and institutional linkages that capitalize on the extreme vulnerability of the urban poor who live in informal settlements. Informal actors have been identified as central to understanding the organization and use of violence in urban areas, particularly in the lives of the poor. These figures are most often referred to by the term 'mastan' and have been associated with a number of roles, including political mobilization and muscle, brokering access to the state and other services, controlling illegal businesses and running extortion networks.

\section{Conclusion:-}

A rising body of evidence now links urban violence to social, economic, and political exclusion and inequality. Neoliberalism creates inequality. At the same, time neoliberal urban development often causes violence and protests in the city of Dhaka. Violence and inequality are mutually constitutive phenomena pointing to structural violence. Structural problems - including climate change, poverty, weak institutions, bad governance, lack of sanitation and access to water, transportation, unsafe roads and streets, together with a culture of misogyny exacerbates structural violence. Social inequality fosters violence, which in turn creates more inequality. Urban violence limits the scope for heempowerment of the urban excluded. In the cyclical process, urban violence could be illustrated and explained as an endemic feature of urban exclusion. More specifically, urban poverty in itself will not normally generate systematic or organized urban violence. But persistent social exclusion, linked to alternative extra-legal sources of 
income and power will provide means and motives for violent actions. In other contexts, violence is fed by the failures of the state to meet its "social contract" responsibilities by delivering services. Thus, any effort to reduce violence must be accompanied by efforts to reduce inequality.

\section{References:-}

1. Bird J., Li Y., Rahman H. Z., Rama M., Venables A. J. 2018. Toward great Dhaka: a new urban development paradigm astward. World Bank Group: Washington.

2. Brenner, N., Jones, M., MacLeod, G., \& Jessop, B. 2003. Introduction: State space in question. In State/space: A reader (pp. 1-26). Boston: Blackwell.

3. Castells, M. 1977. The Urban Question: A Marxist Approach. Edward Arnold, London.

4. Harvey, D. 1973. Social Justice and the City. Johns Hopkins University Press, Baltimore.

5. Harvey, D. 1985. The Urbanization of Capital: Studies in the History and Theory of Capitalist Urbanization. Johns Hopkins University Press, Baltimore. 14

6. Harvey, D. 2003a. The New Imperialism. Oxford University Press, Oxford.

7. Harvey, D. 2003b. The Right to the City. International Journal of Urban and Regional Research, 27 (4), pp. 939-941.

8. Harvey, D. 2009. Social Justice \&The City, Athens: University of Georgia Press.

9. Haque, K. N. 2012. The Political Economy of Urban Space in Dhaka City: "Accumulation by Dispossession". Dhaka: Institute of Global Governance (IGS), BRAC University.

10. Helston, James.2009. Insurgent Citizenship in an Era of Global Urban Peripheries, City \& Society 21(2):245 267

11. Hossain, S. 2004. 'Urban poverty and household adaptations in Dhaka City, Bangladesh', in 'Revising Institutions: Change in the 21st Century', The Australian Sociological Association (TASA).

12. Hossain, S. 2006. Urban poverty in Bangladesh: Slum communities, Migration and Social integration, New York: I.B. Tauris \& Co Ltd.

13. Hossain, S. 2011. Urban Poverty in Bangladesh: Slum Communities, Migration and Social Integration. Basingstoke: Palgrave Macmillan.

14. Lefebvre, H. 1974. The Production of Space. Blackwell, Cambridge, Mass.

15. Mansour, G., Islam, W. and Akhtaruzzaman, M. 2017. Situation analysis of the urban sanitation sector in Bangladesh. https://www.wsup.com/content/uploads/2017/09/Situation-analysis-of-the-urban-sanitation-sectorin-Bangladesh.pdf

16. Moser, Caroline, \&McIlwaine, Cathy. 2006. Latin American urban violence as a development concern: Towards a framework for violence reduction. World Development, 34(1), 89-112.

17. Shafi, S. A., 2010, Urban Crime and Violence in Dhaka. Dhaka: University Press Limited.

18. United Nations, Department of Economic and Social Affairs, Population Division. 2018. The World's Cities in 2018-Data Booklet (ST/ ESA/ SER.A/417). United Nations, 2018. 2018 Revision of World Urbanization Prospects.

19. UN-Habitat, 2007. Global Report on Human Settlements 2007: Enhancing Urban Safety and Security, Earthscan, London.

20. UN Habitat, 2017. Urban Data: Dhaka, urban agglomeration population density (population/km2) in 2013. Available at: http://urbandata.unhabitat.org/da tacity/?cities=6081\&indicators=urban_agglomeration_population_density [Accessed30 March 2019] 15Wacquant, L. 2001. The penalization of poverty and the rise of neo-liberalism. European Journal on Criminal Policy and Research, 9(4), 401-412.

21. World Health Organisation, 2002. World Report on Violence and Health, Geneva. 